\title{
Gambaran skala visual analog dan hemodinamik pada pasien yang diberikan kombinasi tramadol dan ketorolak pasca bedah laparotomi
}

\author{
${ }^{1}$ Galuh R. Mufti \\ ${ }^{2}$ Harold F. Tambajong \\ ${ }^{2}$ Diana Lalenoh
}

\author{
${ }^{1}$ Kandidat Skripsi Fakultas Kedokteran Universitas Sam Ratulangi Manado \\ ${ }^{2}$ Bagian Anestesiologi dan Terapi Intensif Fakultas Kedokteran \\ Universitas Sam Ratulangi Manado \\ Email: galuhmufti2@gmail.com
}

\begin{abstract}
Pain as an unpleasant sensory and emotional experience associated with tissue damage or potential tissue damage or a condition that indicates tissue damage. This study aimed to describe the visual analogue scale (VAS) and hemodynamic among patients given combination of tramadol and ketorolac post laparotomy. Evaluation of pain was assessed by using VAS. This was a descriptive prospective study and was carried out in the recovery room (RR) postoperation and in inpatient A and D instalations of Prof. Dr. R. D. Kandou Hospital Manado from December 2015 to March 2016. There were 20 respondents that were handled with laparotomy and had met the inclusion criteria. The results showed that the average VAS score at the $2^{\text {nd }}$ hour was 5 , while the average VAS score at the $4^{\text {th }}$ hour and the $6^{\text {th }}$ hour were 6.4 and 8.5 respectively. The average systolic pressure at the 2 nd hour was $124 \mathrm{mmHg}$, the $4^{\text {th }}$ hour was $126 \mathrm{mmHg}$, and the $6^{\text {th }}$ hour was $131.6 \mathrm{mmHg}$. The average diastolic pressure at the $2^{\text {nd }}$ hour was $78 \mathrm{mmHg}$, at the 4 th was $80 \mathrm{mmHg}$, and at the $6^{\text {th }}$ was $85 \mathrm{mmHg}$. The average pulse rate at the $2^{\text {nd }}$ hour was 85.4 per minute, at the $4^{\text {th }}$ was 86.7 per minute, and at the $6^{\text {th }}$ was 90.3 per minute. The average MAP at the $2^{\text {nd }}$ hour was $91 \mathrm{mmHg}$, at the 4th was $91.3 \mathrm{mmHg}$, and at the $6^{\text {th }}$ was $94 \mathrm{mmHg}$.
\end{abstract}

Keywords: visual analog scale, haemodynamic, ketorolac, tramadol

\begin{abstract}
Abstrak: Nyeri adalah suatu pengalaman sensoris dan emosional yang tidak menyenangkan dihubungkan dengan adanya kerusakan jaringan atau potensial terjadinya kerusakan jaringan atau suatu keadaan yang menunjukan kerusakan jaringan. Penelitian ini bertujuan untuk mengetahui gambaran skala analog visual dan hemodinamik pada pasien yang diberikan kombinasi tramadol dan ketorolak pascabedah laparotomi. Gambaran nyeri dinilai dengan menggunakan visual analog scale (VAS). Jenis penelitian ini deskriptif prospektif dan dilakukan di ruang pemulihan recovery room (RR) pascabedah dan di Instalasi Rawat Inap A dan D RSUP Prof. Dr. R. D. Kandou Manado pada bulan Desember 2015-Maret 2016. Jumlah sampel yaitu 20 orang yang dilakukan operasi laparotomi yang memenuhi kriteria inklusi. Hasil penelitian menunjukkan bahwa rerata skor VAS pada jam ke-2 ialah 5 sedangkan rerata skor VAS pada jam ke-4 dan jam ke-6 ialah 6,4 dan 8,5 secara berurutan. Rerata tekanan sistolik pada jam ke-2 ialah $124 \mathrm{mmHg}$, jam ke-4 ialah $126 \mathrm{mmHg}$ dan jam ke-6 menjadi 131,6 mmHg. Rerata tekanan diastolik pada jam ke-2 ialah 78 mmHg, jam ke-4 ialah 80 mmHg, dan jam ke-6 menjadi 85 mmHg. Rerata laju nadi pada jam ke-2 ialah 85,4 x/menit, jam ke-4 ialah 86,7 x/menit, dan jam ke-6 menjadi 90,3 x/menit mmHg. Rerata MAP pada jam ke-2 ialah 91 mmHg, jam ke-4 ialah 91,3 mmHg, dan jam ke-6 menjadi 94 mmHg.
\end{abstract}

Kata kunci: visual analog scale, hemodinamik, ketorolak, tramadol 
Nyeri merupakan problem dalam dunia kedokteran karena bukan hanya berkaitan dengan kerusakan dari saraf dan jaringan tetapi juga menyangkut kelainan mediator dan neurotransmiter. Para ahli menyadari pentingnya pengendalian nyeri pascabedah yang adekuat. Masalahnya mencakup aspek manusia dan dikaitkan dengan arti klinis serta biaya yang dikeluarkan. ${ }^{1}$ Nyeri menurut The International Association for the Study of Pain (IASP) yaitu sebagai suatu pengalaman sensoris dan emosional yang tidak menyenangkan dihubungkan dengan adanya kerusakan jaringan atau potensial terjadinya kerusakan jaringan atau suatu keadaan yang menunjukan kerusakan jaringan. ${ }^{2}$

Nyeri merupakan proses mekanisme pertahanan tubuh untuk memberi kesadaran bahwa tubuhnya sedang sakit. Sebagian beranggapan bahwa nyeri merupakan penderitaan yang sangat mengerikan melebihi datangnya maut, dan ketakutan penderita untuk dioperasi ialah kemungkinan adanya nyeri pascabedah setelah pengaruh obat bius hilang. Faktor psikologik juga sangat berpengaruh terhadap perasaan nyeri penderita. ${ }^{3}$

Laparotomi adalah suatu tindakan bedah berupa insisi pada dinding perut atau abdomen. ${ }^{4}$ Setiap insisi atau tindakan bedah selama operasi dapat menimbulkan nyeri, trauma juga dapat menimbulkan gejala kardiovaskuler berupa peningkatan tekanan darah, peningkatan laju jantung dan disritmia. Hal ini dikaitkan dengan respon stres dan refleks simpatis yang berlebihan. ${ }^{5}$

Sekitar 50-70\% pasien yang menjalani pembedahan biasanya mengalami nyeri sedang sampai berat, hal ini menunjukan manajemen nyeri yang baik dan rasional diperlukan untuk mencegah hal tersebut. Manajemen nyeri yang popular belakangan ini yaitu analgesia multimodal. Analgesia multimodal merupakan kombinasi opiod dan nonopiod yang memiliki sel target yang berbeda dalam sistem saraf pusat dan perifer dalam upaya meningkatkan kontrol nyeri, dengan lebih sedikit efek samping opiod seperti sedasi, mual, muntah, pruritis, konstipasi. ${ }^{6}$ Salah satu contoh kombinasi analgesia multimodal yaitu ketorolak dan tramadol.

Pada tahun 2006, terapi kombinasi analgesia tramadol-ketorolak dilaporkan memberikan hasil yang lebih memuaskan dibandingkan penggunaan monoterapi tramadol pada patient-controlled analgesia (PCA). Hal ini disebabkan kombinasi ketorolak-tramadol kurang memberikan efek samping seperti mual, muntah dan keringat berlebih dibandingkan tramadol. ${ }^{7}$ Penelitian lain juga menemukan bahwa pemberian tramadol sebagai mnoterapi biasanya tidak memberikan efek analgetik yang memadai. ${ }^{8}$

Untuk menilai efektifitas obat penilaian nyeri pascabedah penting diperlukan penilaian nyeri secara subjektif, umumnya menggunakan Visual Analog Scale (VAS). VAS merupakan skala berupa suatu garis lurus yang panjangnya biasanya $10 \mathrm{~cm}$ (atau $100 \mathrm{~mm}$ ), dengan pengambaran verbal pada masing-masing ujungnya, seperti angka 0 (tanpa nyeri) sampai angka 10 (nyeri terberat). Nilai VAS $0-<4=$ nyeri ringan, $4-<7=$ nyeri

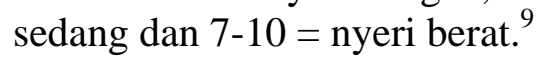

Skor VAS sebagai skala pengukur nyeri biasanya tidak memiliki nilai normal dalam nyeri pascabedah tertentu dalam klinis. Hal ini karena nyeri pascabedah merupakan pengalaman sensorik sekaligus emosional yang sudah dapat diduga terjadi. Gambaran nyeri secara lebih objektif dapat digambarkan melalui perubahan hemodinamik, sehingga dalam klinis kita dapat mengategorikan normal tidaknya peningkatan nyeri yang terjadi disertai pengamatan terhadap kondisi hemodinamik pasien. Selanjutnya dokter lebih memilih menggunakan data klinis seperti laju nadi, tekanan darah, dan MAP dalam menilai nyeri. $^{10}$

Penelitian ini bertujuan untuk mengetahui gambaran skala analog visual dan hemodinamik pada pasien yang diberikan kombinasi tramadol dan ketorolak pascabedah laparotomi.

\section{METODE PENELITIAN}

Jenis penelitian ini ialah deskriptif 
prospektif yang dilakukan di ruang pemulihan recovery room (RR) pascabedah, Instalasi Rawat Inap A (IRINA A) dan Instalasi Rawat Inap D (IRINA D) di RSUP Prof. Dr. R. D. Kandou Manado pada bulan Desember 2015 sampai Maret 2016. Sampel penelitian ialah pasien pascabedah laparotomi yang memenuhi kriteria inklusi dan telah menandatangani lembar surat persetujuan (informed consent) untuk ikut dalam penelitian. Kriteria inklusi dari penelitian yaitu jenis kelamin pria dan wanita, ASA I-III, usia 17-80, lama operasi $<4$ jam, anestesi umum, berat badan sesuai IMT 18,5-22,9, dan pasien yang mendapatkan analgesik pascabedah laparatomi dengan kombinasi tramadol 30 mg IV dan ketorolak $1 \mathrm{mg} / \mathrm{kgBB} / \mathrm{IV}$. Kriteria eksklusi penelitian ini ialah pasien dengan kelainan ginjal, kelainan pembekuan darah, riwayat ulkus peptik, riwayat asma, serta alergi tramadol dan ketorolak. Pengambilan sampel penelitian dengan metode purposive sampling,

Variabel bebas penelitian ini ialah ketorolak $30 \mathrm{mg}$ IV dan tramadol 1 $\mathrm{mg} / \mathrm{kgBB} / \mathrm{IV}$ sedangkan variabel terikat ialah skor nyeri VAS (Visual Analog Scale) dan hemodinamik (tekanan darah, laju nadi, dan MAP).

Pasien yang telah menandatangani informed consent untuk menjadi sampel penelitian dicatat identitas pasien (nama, usia, jenis kelamin, berat badan dan tinggi badan). Pemasangan alat monitor tanda vital dilakukan ketika pasien memasuki ruang operasi kemudian diberikan premedikasi fentanyl dan midazolam sebelum induksi, dilanjutkan dengan anestesi umum. Sebelum jahitan subkutis diberikan analgesik bolus ketorolak $30 \mathrm{mg}$ IV selama 15 detik, kemudian dilanjutkan dengan tramadol $1 \mathrm{mg} / \mathrm{kgbb}$ bolus lambat selama 2-3 menit yang diinjeksikan lewat saluran infus, selanjutnya lama operasi dicatat pada akhir operasi. Skor VAS, tekanan darah, laju nadi dan MAP dinilai setiap 2 jam dihitung pada saat akhir pemberian dari tramadol dan ketorolak hingga 6 jam setelah pemberian obat.

\section{HASIL PENELITIAN}

Berdasarkan data yang telah diperoleh dari ruang pemulihan recovery room (RR) pascabedah RSUP. Prof. Dr. R. D. Kandou Manado, didapatkan sampel penelitian sejumlah 20 pasien. Penelitian dan pengambilan sampel dilakukan pada bulan Desember 2015 dan Maret 2016. Hasil penelitian disajikan menyangkut distribusi umur, jenis kelamin, berat badan, lama operasi, VAS, tekanan darah, laju nadi dan MAP.

Berdasarkan Tabel 1, diperoleh hasil bahwa sampel yang paling banyak ialah wanita yaitu 16 dari 20 pasien (80\%).

Tabel 1. Distribusi pasien berdasarkan jenis kelamin

\begin{tabular}{ccc}
\hline Jenis & $\mathrm{n}$ & $\%$ \\
Kelamin & & \\
Laki-laki & 4 & 20 \\
Perempuan & 16 & 80 \\
Jumlah & 20 & 100 \\
\hline
\end{tabular}

Tabel 2 menunjukkan angka kejadian bedah laparotomi paling banyak pada kelompok umur 41-50 tahun berjumlah 9 pasien.

Tabel 2. Distribusi pasien berdasarkan umur

\begin{tabular}{ccc}
\hline Usia (tahun) & Jumlah & $\%$ \\
\hline $20-30$ & 3 & 15 \\
$31-40$ & 4 & 20 \\
$41-50$ & 9 & 45 \\
$51-60$ & 4 & 20 \\
$61-80$ & 0 & 0 \\
Jumlah & 20 & 100 \\
\hline
\end{tabular}

Tabel 3 menunjukkan angka kejadian bedah laparotomi paling banyak pada kelompok berat badan 51-60 kg berjumlah 9 pasien $(45 \%)$.

Tabel 4 menunjukkan lama operasi bedah laparotomi paling banyak pada lama operasi $60-120$ menit berjumlah 12 pasien (60\%).

Tabel 5 menunjukkan bahwa efek samping paling banyak ialah pusing berjumlah 1 pasien (5\%). 
Tabel 3. Distribusi pasien berdasarkan berat badan

\begin{tabular}{ccc}
\hline $\begin{array}{c}\text { Berat Badan } \\
(\mathrm{kg})\end{array}$ & Jumlah & $\%$ \\
\hline $45-50$ & 2 & 10 \\
$51-60$ & 9 & 45 \\
$61-70$ & 3 & 15 \\
$71-80$ & 5 & 25 \\
$81-90$ & 1 & 5 \\
Jumlah & 20 & 100 \\
\hline
\end{tabular}

Tabel 4. Distribusi berdasarkan lama operasi bedah laparotomi

\begin{tabular}{ccc}
\hline $\begin{array}{c}\text { Lama operasi } \\
\text { (menit) }\end{array}$ & Jumlah & $\%$ \\
\hline$<60$ & 0 & 0 \\
$60-120$ & 12 & 60 \\
$121-180$ & 7 & 35 \\
$181-240$ & 0 & 0 \\
$>240$ & 1 & 5 \\
Jumlah & 20 & 100 \\
\hline
\end{tabular}

Tabel 5. Distribusi pasien berdasarkan efek samping

\begin{tabular}{lcc}
\hline Efek samping & Jumlah & $\%$ \\
\hline Mual & 0 & 0 \\
Muntah & 0 & 0 \\
Pusing & 1 & 5 \\
Bradikardi & 0 & 0 \\
\hline
\end{tabular}

Gambar 1 menunjukkan rerata perkembangan skor VAS pada jam ke-2 yaitu 5 kemudian meningkat pada jam ke-4 menjadi 6,4, dan jam ke-6 menjadi 8,5

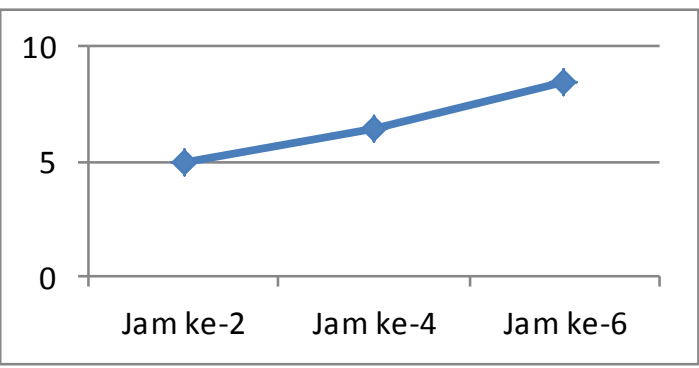

Gambar 1. Rerata perkembangan skor VAS pada jam ke-2, 4 dan 6

Gambar 2 Menunjukan rerata tekanan darah sistolik pada jam ke-2 ialah 124,9 mmHg kemudian meningkat pada jam ke-4 dan ke-6 masing-masing 126,5 mmHg dan
131,6 mmHg. Tekanan darah diastolik pada jam ke-2 ialah $78 \mathrm{mmHg}$ kemudian meningkat pada jam ke-4 dan ke-6 masingmasing $80,2 \mathrm{mmHg}$ dan $84,5 \mathrm{mmHg}$.

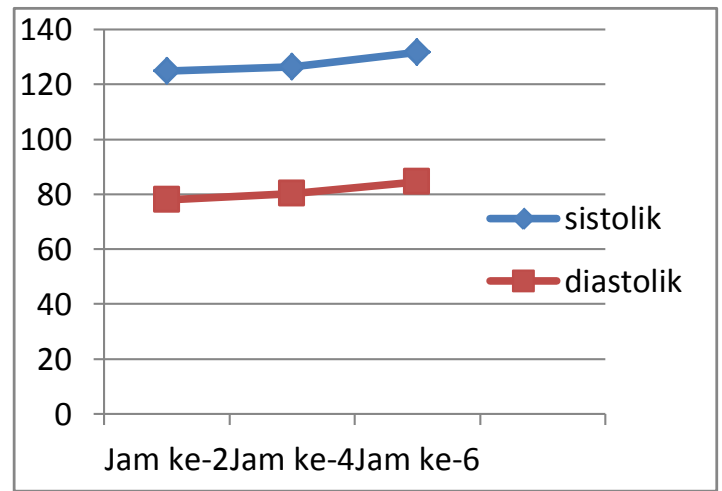

Gambar 2. Rerata tekanan darah sistolik dan diastolik pada jam ke-2,4, dan 6

Gambar 3 menunjukkan rerata perkembangan laju nadi pada jam ke-2 yaitu 85,4 x/menit kemudian meningkat pada jam ke-4 dan jam ke-6 masing-masing 86,7 x/menit dan 90,3 x/menit

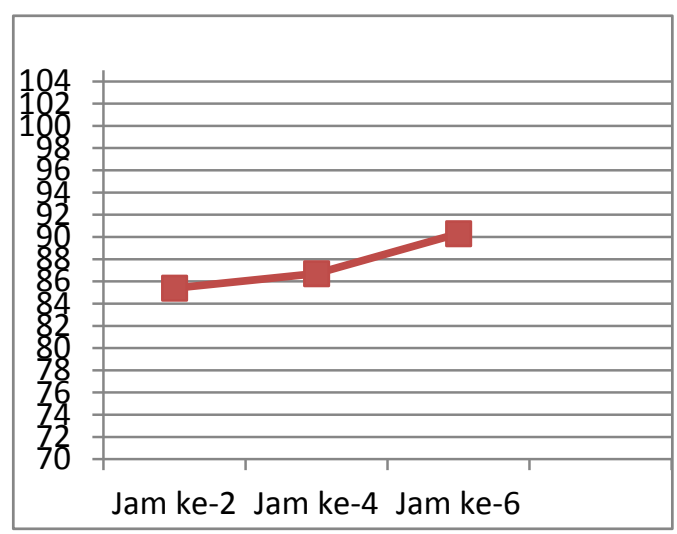

Gambar 3. Rerata laju nadi pada jam ke-2, 4, dan 6

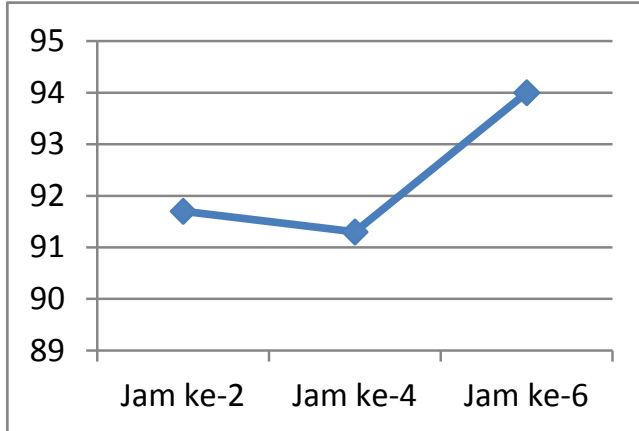

Gambar 4. Rerata MAP pada jam ke-2, 4, dan 6 
Gambar 4 menunjukkan rerata perkembangan MAP pada jam ke-2 yaitu 91,7 mmHg kemudian meningkat pada jam ke-4 dan jam ke-6 masing-masing 91,3 $\mathrm{mmHg}$ dan $94 \mathrm{mmHg}$.

\section{BAHASAN}

Penelitian dilakukan di ruang pemulihan recovery room (RR) pascabedah Instalasi Bedah Sentral (IBS), Instalasi Rawat Darurat (IRD), Instalasi Rawat Inap D (IRINA D), Instalasi Rawat Inap A (IRINA A) RSUP. Prof. Dr. R. D. Kandou Manado pada bulan Desember 2015 sampai dengan Maret 2016. Jumlah sampel 20 orang yang berjenis kelamin laki-laki 4 orang (20\%) dan perempuan 16 orang (80\%) dengan rentang umur 20-80 tahun.

Nyeri pasca bedah merupakan pengalaman sensorik dan motorik yang tidak menyenangkan, yang berhubungan dengan kerusakan jaringan dan bersifat sangat subjektif. Untuk penilaian nyeri secara subjektif umumnya menggunakan visual analog scale (VAS). ${ }^{9}$

Berdasarkan Gambar 1 rerata skor VAS pada jam ke-2 pascabedah laparatomi ialah 5, kemudian meningkat pada jam ke-2 menjadi 6,4 dan meningkat lagi pada jam ke-6 menjadi 8,5. Hal ini disebabkan efek analgesik dari kombinasi tramadol dan ketorolak makin lama akan berkurang dan pasien mulai merasakan nyeri dari derajat sedang bahkan puncaknya pada jam ke-6 dengan nyeri sangat hebat sehingga diperlukan rescue analgetik.

Hal ini sejalan dengan penelitian Onur et al. ${ }^{11}$ pada pasca operasi gigi molar ketiga dengan kelompok T (1 mg/kgBB tramadol) dan kelompok $\mathrm{S}$ (2-mL saline) yang diaplikasikan secara submukosa pascaoperasi. Rasa sakit pasca operasi dievaluasi menggunakan skala analog visual (VAS) 0,5, 1, 2, 4, 6, 12, 24, dan 48 jam pasca operasi. Dalam kelompok T, skor VAS pasca operasi secara bermakna lebih rendah dibanding-kan dengan yang di kelompok S ( $p<0,05)$. Penelitian ini juga menunjukkan bahwa nilai VAS pada kelompok $\mathrm{T}$ meningkat pada jam ke 1 dan ke 4, sedangkan pada penelitian yang dilakukan
Meriwijanti $^{12}$ dengan memban-dingkan obat ketoprofen $100 \mathrm{mg}$ intravena dengan ketorolak $30 \mathrm{mg}$ pasca bedah tonsilektomi dan menemukan bahwa pada kelompok ketorolak terlihat nilai rata-rata VAS, terdapat peningkatan dari menit awal pasca bedah sampai jam ke-12.

Untuk melihat gambaran nyeri secara lebih objektif dapat digambarkan melalui perubahan hemodinamik sehingga dalam klinis kita dapat mengkategorikan normal tidaknya peningkatan nyeri yang terjadi disertai pengamatan terhadap kondisi hemodinamik pasien. ${ }^{13}$ Berdasarkan data tentang distribusi hemodinamik, diperoleh hasil bahwa tekanan darah sistolik rata-rata pada jam ke-2 ialah 124,9 mmHg kemudian meningkat pada jam ke-4 menjadi 126,5 mmHg, dan meningkat lagi pada jam ke-6 menjadi 131,6 mmHg, sedangkan untuk tekanan darah diastolik, rerata tekanan darah diastolik pada jam ke-2 ialah 78 mmHg kemudian meningkat pada jam ke4 menjadi $80,2 \mathrm{mmHg}$, dan meningkat lagi pada jam ke-6 menjadi $84,5 \mathrm{mmHg}$. Pada penelitian laju nadi rata-rata pada jam ke-2 ialah 85,4 x/menit kemudian meningkat menjadi 86,7 x/menit pada jam ke-4, dan meningkat lagi menjadi 90,3 x/menit. Penelitian ini juga menunjukkan bahwa MAP pada jam ke-2 ialah 91,7 mmHg kemudian meningkat pada jam ke-4 menjadi 91,3 mmHg, dan meningkat lagi menjadi $94 \mathrm{mmHg}$.

Hal ini dikarenakan respon fisiologis terhadap nyeri meliputi peningkatan tekanan darah, denyut nadi, pernapasan, keringat, diameter pupil dan ketegangan otot. Respon ini disebabkan oleh refleks simpatis yang berlebihan dimana hal ini akan berbahaya bagi prenderita dengan faktor risiko seperti hipertensi, coronary artery disease, cerebrovaskular disease dan aneurisma intrakranial. ${ }^{14,15}$ Penelitian Schwenzer KJ et al. melaporkan bahwa pemberian ketorolak $30 \mathrm{mg}$ IV tidak berpengaruh terhadap tekanan sistolik dan diastolik karena ketorolak selektif menghambat enzim cyclooxygenase-1 (COX-1) dan sintesis prostaglandin yang berakibat terhambatnya impuls nyeri di 
perifer tanpa memengaruhi reseptor opiod; dengan demikian tidak memengaruhi nilai hemodinamik. $^{16}$

Ajartha $^{17}$ menemukan bahwa pada pasien yang diberikan tramadol intravenous tidak terdapat perbedaan bermakna pada tekanan darah sistolik dan diastolik. Rerungan $^{18}$ juga tidak menemukan adanya perbedaan bermakna pada tekanan darah sistolik, diastolik, dan nadi. Hal ini disebabkan karena tramadol bekerja sentral pada neurotransmitter noradrenergik dan serotonergik dengan meningkatkan aktivitas saraf penghambat monoaminergik menyebabkan terhambatnya transmisi nyeri sehingga tekanan darah tidak akan meningkat. Long dan Yue ${ }^{19}$ juga menemukan tidak adanya perbedaan bermakna pada frekuensi nadi pada pasien yang diberikan tramadol IV. Tabel 5 menunjukkan bahwa efek samping paling banyak ialah pusing berjumlah 1 pasien (5\%). Hal ini dikarenakan efek samping yang umum antara lain mual, muntah, mulut kering, sedasi, dan sakit kepala. Penggunaan ketorolak oral juga dapat menyebabkan somnolen, sakit kepala, nyeri gastrointestinal, dispepsia, mual, dan nyeri di tempat suntikan. ${ }^{8,20}$

\section{SIMPULAN}

Berdasarkan hasil penelitian ini dapat disimpulkan bahwa:

1. Rerata skor VAS pada jam ke-2 ialah 5, meningkat menjadi 6,4 pada jam ke-4, dan meningkat lagi pada jam ke-6 menjadi 8,5

2. Rerata tekanan darah sistolik pada jam ke-2 ialah $124 \mathrm{mmHg}$, meningkat pada jam ke-4 menjadi $126 \mathrm{mmHg}$, dan kemudian meningkat lagi pada jam ke-6 menjadi 131,6 mmHg.

3. Rerata tekanan darah diastolik pada jam ke-2 ialah $78 \mathrm{mmHg}$, meningkat pada jam ke-4 menjadi $80 \mathrm{mmHg}$, dan meningkat lagi pada jam ke-6 menjadi $85 \mathrm{mmHg}$.

4. Rerata laju nadi pada jam ke-2 ialah 85,4 x/menit, meningkat pada jam ke-4 menjadi 86,7 $\mathrm{x} /$ menit, dan meningkat lagi pada jam ke-6 menjadi 90,3 $\mathrm{x} /$ menit.

5. Rerata MAP pada jam ke 2 ialah 91,7 mmHg, menurun pada jam ke-4 menjadi 91,3 mmHg, dan meningkat lagi menjadi $94 \mathrm{mmHg}$.

\section{SARAN}

Perlu penelitian lanjut dengan kombinasi obat yang up to date. Disarankan untuk penelitian lanjut agar dapat lebih memahami penggunaan VAS serta dapat membandingkan dengan skala penilaian nyeri yang lain.

\section{DAFTAR PUSTAKA}

1. Knape KG. Postoperative Analgesia In Geriatric Patients. In: Smith RB, Gurkowski MA, Bracken CA. Anesthesia And Pain Control In The Geriatric Patient. New York: Mc Graw-Hill Inc, 1995; p. 457-75.

2. H. Merskey, Bogduk N. IASP Taxonomy. 1994. [cited 2015 Oct 11]. Available from: http://www.iasppain.org/Taxonomy.

3. Riwanto I. Pengelolaan Nyeri Pascabedah. In: Soetedjo, Indra W, Hertanto WS, Soeharyo H, editors. Penatalaksanaan Nyeri Masa Kini dan Mendatang. Semarang: Badan Penerbit Universitas Diponegoro, 1996; p. 149.

4. Sjamsuhidajat, Jong. Buku Ajar Ilmu Bedah (2nd ed). Jakarta: EGC, 2005; p. 620-38.

5. SIGN. Postoperative Management In Adults: a practical guide to postoperative care for clinical staff. Scottish intercollegiate guidelines network.2004. [cited 2015 Oct 11]. Available from: http://rove.nla.gov.au/work/8679732 ?selectedversion=NBD26544129

6. Carr DB, Goudas LC. Acute pain. Lancet. 1999;353:2051-8.

7. Lepri A, Sia S, Catinelli S, Casali R, Novella G. Patient-Controlled Analgesia with Tramadol Versus Tramadol Plus Ketorolac. Minerva Anestesiol. 2006;72:59-67.

8. WHO. Tramadol Update Review Report: Expert Committee On Drug Dependence Thirtysixth Meeting. Geneva. 2014. [cited 2015 Oct 11]. 
Available

from:

http://www.who.int/medicines/areas/q uality_safety/6_1_Update.pdf

9. Keefe FJ, Holzberg AD, Beaupre PM. Contributions of pain behavior assessment and pain assessment to the a development of pain clinics. In: Cohen MJ, Campbell JN, editors. Pain treatment centers at a crossroads. A practical and conceptual reappraisal. Seattle: IASP press, 1996; p. 79-99.

10. Lecher DE, Bradbury SF, Bradley LA. Detecting sincerity of effort: a summary of metods and approaches. Phys ther. 1998;78:867-88.

11. Onur G, Satılmış T, Ferit B, Gökhan G, Aysegül S, Kamil G. Effect of Submucosal Application of Tramadol on Postoperative Pain After Third Molar Surgery. Head \& Face Medicine, 2015;11:35.

12. Meriwijanti. Evaluasi Efek Analgesi Pemakaian Ketoprofen dan Ketorolak Intravena Pasca Tonsilektomi [Skripsi]. Semarang: FK-Universitas Diponegoro; 2011.

13. Hartawan D. Efektifitas Pemberian Lidocain Intravena $1,5 \mathrm{mg} / \mathrm{kg} / \mathrm{jam}$ Untuk Nyeri Pada Pasien Pasca Laparatomi Di RSUP Dr. Kariadi Semarang Faculty of Medicine [Skripsi]. Semarang: Diponegoro University; 2012.
14. Scott B. Groudine, MD, et al. Intravenous Lidocain Speeds the Return Of Bowel Function, Decreases Postoperative Pain, and Shortens Hospital Stay In Patients Undergoing Radical Retopubic Prostatectomy. Anesth Analg. 1998;86:235-9.

15. Mallick A, Klein H, Mosse E. Prevention of Cardiovascular Response to Tracheal Intubation. $\mathrm{Br} \mathrm{J}$ Anesth. 1996:296-77.

16. Gillis JC. Brogden RN. Ketorolac A Reappraisal of its Pharmacodynamics and Pharmacokinetic Properties and Therapeutic Use in Pain Management. Drugs.1997;53(1):13988.

17. Ajartha R. Efek Pemberian Tramadol Intramuskular Terhadap Nyeri Persalinan Pada Primigravida [Tesis]. Medan: FK-USU; 2008.

18. Rerungan E. Penggunaan Modifikasi Analgesia Balans sebagai Metode Pengelolaan Nyeri Persalinan Normal [Tesis]. Makassar: Bagian Obstetri dan Ginekologi Universitas Hasanuddin; 2002.

19. Long J, Yue $\mathbf{Y}$. Patient Controlled Intravenous Analgesia with Tramadol for Labor Pain Relief. Chin med J. 2003;116(11):1752-5.

20. Gunawan SG, Nafrialdi RS, Elysabeth. Farmakologi dan Terapi (5th ed). Jakarta: FKUI, 2011; p. 228-44. 